\title{
A Literary Study of the Chinese Version of the Gatha of Buddhist Scriptures*
}

\author{
Lili Chen \\ Northwest Minzu University \\ Lanzhou, China
}

\author{
Lengben Zhaxi \\ Gansu Normal University for Nationalities \\ Hezuo, China
}

\begin{abstract}
As a rhyme composed of specific syllables and length, the gatha has the same side with Chinese traditional poetry, but also has great difference. From the perspective of literature, this paper takes the Chinese version of the gatha of Buddhist scriptures in the Period of Wei, Jin, Southern and Northern Dynasties to discuss the cultural elements of it from the aspects of content and form.
\end{abstract}

Keywords-Wei, Jin, Southern and Northern Dynasties; Chinese version of the gatha of Buddhist Scriptures; Content classification; form analysis

\section{INTRODUCTION}

Gatha is the synonym of transliteration and free translation of Sanskrit, and it is also called Gatha for short. In the volume 2 of biography of Kumarajiva, it is recorded that Kumarajiva said to the monk Rui, "The verses of the Buddhist scriptures from India attach great importance to its poetic style which is suitable for chanting. They are used to praise the king's merits and virtues, and extol the beneficence and grace of Buddha." 1It is indicated that gatha is a kind of rhythmic poem in ancient India, and it is not a patent of Buddhist literature. In Indian customs, gatha is the main form of eulogizing and praise, which can be used in singing, similar to eulogy in Chinese poetry, so it is translated as "gatha" in the way of Sino-sanskrit symmetry.

In Sanskrit literature, gatha has the characteristics of paying attention to pattern and neat sentence pattern, which is consistent with Chinese classical poetry. However, in the process of translation, due to the complete difference between the two language systems, the translator first considers the transmission of the content, and has to abandon the original pattern, making the gatha into a literary form like poetry but not poetry with neat system.

* This paper is funded by projects named in 《Tibetan $<$ Tripitaka $>$ Ten Kinds of Electronic Databases Version Construction and Research》 [13JZDD28]、 《Study on Tibetan Named Entity Recognition and Entity Knowledge Base Construction》[15CYY043] and National Language Intelligent Processing Key Laboratory of Gansu Province (Northwest University for Nationalities);

Hui jiao. Biographies of Eminent Monks, volume 2. Beijing: Zhonghua Book Company, 1997, p. 53.

\section{AN ANALYSIS OF THE CONTENTS OF CHINESE VERSION OF THE GATHA OF BUDDHIST SCRIPTURES}

The content of the gatha in the Han, Wei, Jin, Northern and Southern Dynasties can be divided into the following categories:

\section{A. Reasoning}

Buddhist scriptures are the scriptures and writings that embody the Buddhist thoughts of different historical stages, different Buddhist denominations and great virtue of eminent monks in the development history of Buddhism. In short, Buddhist scriptures express Buddhist ideas and main ideas in a specific and explicit way to make people understand doctrine and influence sentient beings to be devoted to good As an important part of Buddhist scriptures and classics, argument and reasoning is the main means and purpose of Chinese version of the gatha of Buddhist scriptures in Wei, Jin, Northern and Southern Dynasties. Therefore, reasoning is one of the main contents of the gatha

Reasoning gatha expresses buddhist views on the universe, life, and all things and buddhist doctrine in the form of melodious rhyme, so as to achieve the purpose of capturing the public's will with fewer words. This kind of gatha either purely illustrates the Buddhist doctrine, or express through examples. The reasoning atmosphere is either strong or weak, not the same.

For example, there is a gatha in Diamant-Sutra translated by Yao Qin Kumarajiva, which reads as follows:

All conditioned phenomena are like a dream, an illusion, a bubble, a shadow. Like dew or a flash of lightning; thus we shall perceive them. 2

That is to say, all the phenomena and things that are formed due to destiny in the world are temporary and unreal like dreams and disillusionment. Because things are made of conditions, once the conditions of existence of things disappear, things will disappear. All things are temporary and will dissipate. It tells people the truth of the uncertainty of life and origin empty by comparing dream, morning dew, and lightning to everything in the world. $8.752 \mathrm{~b})$ 
For another example, in all dharmas without compass translated by Kumarajiva, a very profound Mahayana scripture, there is gatha saying that greed, hatred, infatuation, and precepts, determination, and wisdom are all the Tixing of equal dharmadhatu, which intends to explain that the reality of the all Dharma is nothing. That is to say, the real appearance of all phenomena in the world is generated due to false destiny, and there is no fixed and unchangeable existence. It aims to persuade the public not to be too obsessed with external interest.

\section{B. Encouragement}

In the Chinese version of the gatha of Buddhist scriptures in Han, Wei, Jin, and Northern and Southern Dynasties, in addition to recording the Buddha's preaching to all living beings and disciples and explaining the Buddhist doctrine, many pieces of the gatha encourage and commend the practitioners to preach the wonderful enlightenment of the Buddha Dharma and increase their confidence.

For example, there is a gatha in the punna meeting in Ratnakuta translated by Kumarajiva intending to say that if the devotees diligently support the Pagoda temples with their flowers and wreaths, banner covers, prostitute's music, and all the beautiful things, they will be blessed by Bodhisattva, and all their meritorious deeds will be fulfilled. For example, in Madh yamagama-sutra translated by Gautama Savghadeva of the Eastern Jin Dynasty, there is a gatha descirbing that the Buddha explains to his disciples Bhiksu the reason for "What is the results and causes that make me happy today?" 3to encourage the disciples to be faithful to the Buddha and to have a wide variety of good roots, so as to obtain the protection of the Buddha.

The examples above are just a few in many gathas. Through these two examples, it can be seen that the encouraging disciples to practice the Dharma is one of its main contents. There is also a kind of gatha which is opposite to it in content with the same purpose, namely gatha by means of exhortation.

\section{Exhortation}

The so-called exhortation gatha is to explain the evil retribution apart from advocating one good turn deserves another in the Han, Wei, Jin, Northern and Southern Dynasties.

For example, in Sublime Dharma of Clear Recollection translated by gautama prajnaruci, there is a gatha indicating that all living beings have the time when blessing and return are used up and the speed is as fast as the speed of a bird flying in a storm, which is fleeting, so as to admonish the people that they should not only seek the pleasures of this world, but forget to practice good deeds just as a foolish man who, at the end of his blessing, does not know himself, and eventually goes to ruin."

Gautama Savghadeva tr. The Medium Works of Hinayana Sutra, Vol. 34, The Book of Dapingfu, (Taisho-pitaka, 1.646b)
In the seventh volume of the obsidian translated by Yao Qin, there is a gatha in which the Buddha encourages the disciples to be devoted to their own lives both day and night, without seeking pleasure and staying ease endlessly to accumulate all kinds of evil. Otherwise, when the causes come into being, the consequences of evil will be endless.

\section{Oath}

Among the Chinese version of gatha of Buddhist scriptures in the Han, Wei, Jin, Northern and Southern Dynasties, there is a kind of gatha which express the admiration of Buddha dharma and praise of Buddha, but they are spoken in the oath of the first person, and thus become more appealing.

For example, in the volume 19 Ninth Treasure house and Mokupin first in Mahavai pul ya-mahasanni-pata-sutra translated by Dharmakșema in Northern Liang, there is a gatha that is first-person oath that expresses the determination before the conversion to the buddha, followed by a description of the buddha's various divine powers and virtues, which frightens the demons who have the confidence after seeing the divine power of buddha, so they make an oath of the will before the conversion to the buddha.

Similarly, in volume 4 of the book "To ask the heart of Brahma" translated by Dharmarakșa in the Western Jin Dynasty, there is a gatha that release the prince for the emperor of heaven, whose name is Zhai or making an oath in front of the Buddha to indicate the determination and ambition to give all one's heart to the Buddha and to uphold the correct method until becoming Buddha. The oath in a first-person tone can be described as surging forward with great momentum such as rainbow. There are many such gathas in the Chinese version of Buddhist scriptures in the Han, Wei, Jin, Northern and Southern Dynasties.

The above four types of gatha, including reasoning, encouragement, exhortation, and oath, are expressions of Dharma righteousness and can also be classified into one category.

\section{E. Praise}

In Indian Buddhist scriptures, "praise" is a style closely related to "verse and "eulogy". Also known as "paean" and "eulogy", it refers to the verse and chapters that praise Buddha, Bodhisattvas, their ancestors merit, Buddhist scriptures and Dharma and so on, which is also a kind of gatha with musicality that can be sung. There are many praise gathas in scriptures that admire Buddha's virtue. The form is generally: first described by long line, and then repeated by the rhyme. Before the gatha, "it is praised as" or "it is eulogized as" are used as introduction.

For example, in the fourth volume of Scripture of Dragon King translated by Dharmarakșa in the Western Jin Dynasty, there is a gatha that praise the Buddha, saying that Buddha has 32 kinds of solemn demeanor and no one refuses to express his admiration for the Buddha. This gatha is a gatha of five characters, with each four sentences in a group. It first praises the merit of the Buddha, and then expresses the 
determination of converting to the Buddha. For example, there is seven-character gatha in Mahayana Paoyun Scriptures, which praises the Buddha for his special and wonderful deeds and virtues by parallelism, and show the determination of those who want to convert to Buddhism.

\section{F. Narration}

The so-called narrative gatha is another kind of gatha which differs from the pure reasoning to explain Buddhist doctrine and preach sentient beings. It is more storytelling, and generally explains the cause process and results of the whole event The plot twists and turns and the story is fascinating. There are a lot of narrative gathas about the life of Buddha and the Buddhist universe and outlook on life in terms of figurative stories in the Chinese version of gatha of Buddhist scriptures in Han, Wei, Jin, Northern and Southern Dynasties, which are represented by the gatha in Buddhacarita, Buddhism borrowed, Jataka tales and Agama. This kind of gatha is mostly expressed in the form of a long narrative, such as Buddhacarita translated by Dharmakșema in Northern Liang Dynasty, which tells the story of Sakyamuni's deeds from birth to nirvana. The whole sutra is presented in the form of the gatha of five characters, with a total of 9,113 sentences. For example, there is a gatha in Out of town, depicting Sakyamuni Buddha as a prince in the palace before he became a monk. His father didn't want to let him go, so he held party every night and sent sons of notable families to hang out with the prince every night to win the favor of the prince. However, he did not succeed. Later, he arranged women to serve him in order to inherit offspring, but in vain. The gatha unfolds slowly in the way of narration, and describes all the stories in detail, with a complete structure, a tortuous plot and a rich language, which can be called an excellent long narrative poem

As in the volume 1 Nanda in "The Five Hundred Disciples tell their origins" translated by Dharmarakșa in Western Jin Dynasty, there is a gatha that mainly tell that Buddha was once a man of wealth and dignity, but he fell into the hell because of evil in his previous life and then he became a monk to achieve success. The whole scripture is presented in the form of gatha with a tortuous plot and a complete structure.

Compared with the above five kinds of gatha, most of the narrative gathas are longer, and the language is plainer, fresher, and simpler and clearer, which has a more profound impact on the traditional Chinese poetry. This issue is going to be discussed in the next section, so we don't repeat give unnecessary details here.

To sum up, the content of the Chinese version of gatha of Buddhist scriptures in the Han, Wei, Jin, Northern and Southern Dynasties can be roughly divided into six categories: reasoning, encouragement, exhortation, oath, praise and narration. The first four can also be said to be the gatha about the Buddhist philosophy, which together constitute the rich content of the Chinese version of gatha of Buddhist scriptures.

\section{AN ANALYSIS OF THE ARTISTIC FORM OF CHINESE VERSION OF THE GATHA OF BUDDHIST SCRIPTURES}

In the period of Han, Wei, Jin and Northern and Southern Dynasties, the flourishing development of the translation of Buddhist scriptures led to the production of numerous Chinese version of the gatha of Buddhist scriptures. On the basis of the classification and explanation of the main contents, it can be found that Chinese version of the gatha of Buddhist scriptures also has its own characteristics in form, which have a certain connection with the development of traditional Chinese poetry.

\section{A. The Combination of Neat Sentences and Loose Sentences}

The Chinese version of the gatha of Buddhist scriptures mainly includes Jeyata and Gatha. The main feature of Jeyata is repeating the content mentioned in the preceding long verses, while the long verses are written in the form of prose. Most of Jeyata are written in the verse of neat speech. The two constitute an organic whole, so they are the combination of whole sentences and loose sentences. In Buddhism and Chinese Literature, Mr. Sun Changwu also call this form of combination of gatha and long verses the combination of rhyme and prose. In the period of Han, Wei, Jin and Northern and Southern Dynasties, this kind of form of the combination of long verses with gatha is very extensive in the Chinese version of the gatha of Buddhist scriptures. As mentioned above, in Ligou womam scripture translated by Dharmarakșa in the Western Jin Dynasty, there is a paragraph recording the Buddha show to the Ligou woman how to obtain great wisdom. After the long verse, the gatha immediately follows and repeats the content of the long verse. The long line is written in the form of prose, while the gatha is written in the form of poetry of neat speech. However, the part of neat speech is not rhymed and has some differences with the traditional Chinese poetry. Therefore, this kind of prose and the form of neat speech are called the combination of neat sentences and loose sentences.

\section{B. Long Neat Speech}

In the development history of Chinese traditional poetry, the long literary pieces over a hundred sentences such as "the Peacock Flies to the Southeast" and Cai Yan's "indignant poem" is rare. Qu Yuan's Li Sao has a total of 373 sentences, which can be described as a long literary piece, but the stylistic attribute of $\mathrm{Li} \mathrm{Sao}$ is not clear. If $\mathrm{Li} \mathrm{Sao}$ is regarded as a poem, it is undoubtedly a long literary piece rarely seen in the history of Chinese poetry. However, if $\mathrm{Li} \mathrm{Sao}$ is regarded as a work of $\mathrm{Fu}$ style, there is no long poem in China before "the Peacock Flies to the Southeast" and "indignant poem".

However, in the Chinese version of Buddhist scriptures, there are a lot of long gathas with neat forms and meat speech, which often have hundreds of sentences, thousands of sentences, and even tens of thousands of sentences. For example, Dhammapada translated by $\mathrm{Wu}$ Guowei and so on, contains totally 39 sections, which are all presented in the form of four-character, five-character or seven-character gatha, a total of 3100 sentences; The Five Hundred Disciples 
of the Buddha Saying the Original Scripture translated by Dharmarakșa in the Western Jin Dynasty is consisted of 30 sections, all of which are presented in the form of fivecharacter or seven-character gatha, with a total of 2032 sentences. And the Manjusri Scripture translated by Buddhabhadra in the Eastern Jin Dynasty is presented in the gatha of the five characters, with 176 sentences in total. Buddhacarita translated by Dharmakșema in Northern Liang Dynasty is also presented in the form of five-character gatha, with a total of 9113 sentences. The Buddhist scriptures mentioned above preach in the form of gatha of neat speech, where there is no long verse interspersed in it, and the number of sentences is huge evidently. The above is only the tip of the iceberg in many long gathas. However, it can be seen that there are translation of long gathas in each period. The appearance of this kind of long neat speech must have certain influence on Chinese traditional poetry.

\section{Free Structure}

From the examples mentioned above, it can also be known that the Chinese version of the gatha of Buddhist scriptures in the Han, Wei, Jin, and Northern and Southern Dynasties are relatively free in form and structure. They can be the gatha composed of three words, four characters, five characters, six words, seven characters, eight words and nine words, or mixed words. At the same time, the number of sentences of the Chinese version of the gatha of Buddhist scripture is not fixed, which can be two, four and even a hundred, a thousand, or tens of thousands of sentences. Moreover, the sentence patterns are also varied, but generally speaking, the Chinese versions of the gatha of Buddhist scripture in this period are mainly composed of fivecharacter gatha, followed by four-character and sevencharacter gatha.

In the period of Han, Wei, Jin, Northern and Southern Dynasties, the expression form of the Chinese version of the gatha of Buddhist scripture is similar to the development of traditional Chinese poetry. After the Han Dynasty, the fourword style of The Book of Songs and the mixed-character style of Li Sao have gradually withdrawn from the historical stage. The style of the five-character poems began to show a trend of prosperity. Accordingly, during this period, the Chinese versions of the gatha of Buddhist scriptures are mostly written in five characters. For example, there are 28 sentences of the five-character gatha in The Parable Sutra of the Five Yin, translated by An Shigao in the Eastern Han Dynasty. There are three 24 sentences Five-character gatha in the Pangzhou Samadhi Scriptures translated by Buddhabhadra in Eastern Jin Dynasty, which are all presented in five-character gatha, with 176 sentences in total. And Buddhacarita translated by Dharmakșema in Northern Liang Dynasty is presented in five-character gatha, with a total of 9113 sentences. All of the above show the side that Chinese version of the gatha of Buddhist scripture is in the same step with the popularity of Chinese traditional poems.

\section{CONCLUSION}

In the period of Han, Wei, Jin and Northern and Southern Dynasties, the content of the Chinese version of the gatha of
Buddhist scripture is mainly based on the interpretation of Buddhist doctrine, including pure reasoning, exhortation and encouragement. At the same time, there are praise of Buddhist and narrative gatha. In form, both the combination of neat sentences and loose sentences and the combination of the long neat speech are free and unique; In terms of expression techniques, the Chinese version of the gatha of Buddhist scripture use a variety of rhetoric to enhance the appeal; Due to the nature of the gatha, the language of Chinese version of the gatha of Buddhist scripture in the Han, Wei, Jin, Southern and northern dynasties is not only simple, elegant and solemn, but also has a strong exotic color.

\section{REFERENCES}

[1] [Liang] Shihui Jiaon, Tang Yongtong, Tang Yixuan. Biographies of Eminent Monks [M]. Beijing: Zhonghua Book Company, 1992.

[2] [Liang] Shi Sengyou, Su Jinren. Compilation of Notes on the Translation of the Tripitaka [M]. Beijing: Zhonghua Book Company, 1995 .

[3] [Liang] The monk wrote. Hong Ming Ji [M]. Shanghai: Shanghai Ancient Books Publishing House, 1991.

[4] Sun Shangyong. Studies on Buddhist Classic Poetics [M]. Higher Education Press, 2013.

[5] Chen Yuan. Introduction to Chinese Buddhist History: Volume Six [M]. Beijing: Zhonghua Book Company, 1962.

[6] Ding Fubao tr.. A Dictionary of Buddhism [C] Beijing: China Bookstore Publishing House, 2011. 